\title{
Australian Osteopathic Practitioners' Perceptions of the Clinical Relevance of Anatomy
}

\author{
Percepciones de los Practicantes de Osteopatía \\ Australianos de la Relevancia Clínica de la Anatomía
}

Raymond Blaich ${ }^{1}$; Nalini Pather²; Kehui Luo ${ }^{3}$ \& Goran Strkalj ${ }^{4}$

\begin{abstract}
BLAICH, R.; PATHER, N.; LUO, K. \& STRKALJ, K. Australian osteopathic practitioners' perceptions of the clinical relevance of anatomy. Int. J. Morphol., 37(1):319-323, 2019.
\end{abstract}

SUMMARY: Anatomy is a foundational discipline in the training of health care professionals. However, there is a paucity of literature on the relative importance of anatomy, especially in relation to the other biomedical sciences and clinical domains, in preparing osteopathic practitioners for clinical practice. This study aimed to examine Australian osteopathic practitioners' perceptions of the relative importance of anatomy in their professional training and clinical practice, especially in relation to other biomedical sciences and clinical domains within osteopathic curricula. The study also examined the perceived importance of the sub-disciplines of anatomy to professional practice. A questionnaire-based survey was carried out among Australian osteopathic practitioners at several national meetings in 2014 and 2015. Using a five-point Likert scale, all respondents were asked to rate the relevance of the following thirteen disciplines and subdisciplines to clinical practice: biomechanics, biochemistry, embryology, histology, gross anatomy, microbiology, neuroanatomy, neurology, pathology, pharmacology, physical examination, physiology and radiology. Out of 175 practitioners surveyed, 169 responded (i.e., 96.6 $\%$ response rate). Two of the sub-disciplines of anatomy were among the highest rated, with $98.2 \%$ perceiving gross anatomy as "very important" while neuroanatomy being rated as "very important" by $84.6 \%$ and "quite important" by $14.2 \%$. Similar high rating was also given to biomechanics and physical examination while the other two sub-disciplines, embryology and histology received lower ratings. No significant difference in ratings were identified with regard to participants' year and place of graduation. However, there was an association between gender and rating on Pathology and Pharmacology respectively, as well as age effects on the ratings of several sub-disciplines. These findings are generally consistent with the results from similar surveys carried out on the clinical importance of anatomy in other medical and allied health professionals in different countries. Overall, osteopathic practitioners have a positive perception of the relevance of anatomy, particularly gross and neuroanatomy, to clinical practice, and this should be taken into account when developing osteopathic curricula.

KEY WORDS: Anatomy; Osteopathy; Education; Curriculum development.

\section{INTRODUCTION}

Anatomy has always been regarded as a cornerstone discipline in the education of health professionals (Shank, 1984; Turney, 2007; Estai \& Bunt, 2016; Duman, et al., 2017). History bears witness that the relationships between structure and function of the human form have been foundational concepts in all medical and most of the life sciences disciplines (Persaud et al., 2014). Several studies have been published, which strongly suggest that medical and allied health students and practitionersview anatomy as one of the most important preclinical subjects (Pabst \& Rothkötter, 1997; Moxham \& Plaisant, 2007; Lazarus et al.,
2012; Plaisant et al., 2014; Strkalj et al., 2014). A thorough understanding of anatomy is vital to clinical practice; in the accurate diagnosis of conditions, in the selection and performance of safe and effective treatment interventions, and in facilitating inter-professional communication (Turney; Plaisant et al.; Estai \& Bunt; Giuriato et al., 2016).

Osteopathy is an allied health profession in which a sound knowledge of anatomy has been seen to play a prominent and vital role. Indeed, Osteopathy Australia, the peak professional body for osteopaths in Australia, notes

\footnotetext{
${ }^{1}$ School of Health and Human Sciences, Southern Cross University, Lismore, Australia.

${ }^{2}$ School of Medical Sciences, University of New South Wales, Sydney, Australia.

${ }^{3}$ Department of Statistics, Macquarie University Sydney, Australia.

${ }^{4}$ Department of Chiropractic Macquarie University, Sydney, Australia.
} 
that "osteopaths focus on how the skeleton, joints, muscles, nerves, circulation, connective tissue and internal organs function as a holistic unit" (Osteopathy Australia, 2018). Andrew Taylor Still, the founder of osteopathy, placed strong emphasis on anatomical knowledge advocating that his students "have and keep a living picture before you in your mind all the time, so you can see all joints, ligaments, muscles, glands, arteries, veins, lymphatics, fascia superficial and deep, all organs" (Still, 1899). However, apart from anecdotal evidence, there is a paucity of data on osteopathic practitioners' perceptions of the importance of anatomy, and consequently a perceived lack of support for maintaining anatomy as a significant domain in osteopathic education and practice. In addition, the current Australian national accreditation requirements for osteopathic education make no mention of the anatomical sciences (Australasian Osteopathic Accreditation Council, 2016).

The aim of this study therefore was to investigate Australian osteopathic practitioners' perceptions of the importance of anatomy in their osteopathic training and clinical practice, and to compare these to perceptions of the importance of other biomedical sciences and clinical domains within osteopathic curricula. In light of the redesigning of allied health curricula in the Australia due to changes in both the higher education landscape, and concomitant requirements of accreditation, it is important to be informed by practitioners' perceptions of the role of disciplines such as anatomy in clinical practice. Program developments will potentially affect both the time allocated for anatomy teaching, and its content and delivery (Paulsen et al., 2015). This study was therefore undertaken to contribute towards elucidation of the role of biomedical sciences in training future graduates

\section{MATERIAL AND METHOD}

A questionnaire-based survey was designed and delivered to Australian osteopathic practitioners to determine participant's perceptions of the biomedical sciences and clinical domains in developing clinical skills for osteopathic practice. The questionnaire gathered information of participant's age, sex, year of osteopathic graduation and graduating institution. The survey included thirteen different biomedical sciences and clinical disciplines, four of which are sub-disciplines of anatomy: embryology, histology, gross anatomy and neuroanatomy. The remaining nine disciplines were biomechanics, biochemistry, neurology, microbiology, pathology, pharmacology, physical examination, physiology and radiology. Respondents were asked to rate each discipline in terms of its importance for clinical practice on a five-point Likert scale of "not important", "slightly important", "moderately important", "quite important" and "very important".

The questionnaires were distributed at the Australian Osteopathic Association (now Osteopathy Australia) 2014 conference and also at a number of postgraduate osteopathic workshops held in 2014 and 2015. This study has been approved by the Southern Cross University Human Research Ethics Committee (ECN-14-242). Descriptive statistics including proportion were used to analyse the data, chisquared test and ANOVA method were used to investigate association between each categorical outcome variable and factors considered in the study, such as sex and age.

\section{RESULTS}

The total number of attendees at the meetings, in which the survey was conducted, was 175 . Of this, 169 participated in the survey, representing a response rate of $96.6 \%$. Table I shows the respondents' perceptions of the relevance to clinical practice for the thirteen disciplines of interest, respectively.

Among the most highly rated in importance for clinical practice were two sub-disciplines of anatomy - gross anatomy and neuroanatomy. Gross anatomy was the highest ranked discipline (98.2\% rated "very important"), followed by physical examination, biomechanics and neuroanatomy (94.7\%, $85.8 \%$ and $84.6 \%$, respectively). These four disciplines were perceived to be considerably more important for clinical practice. Neurology and physiology were perceived to be the next "very important" disciplines for practice $(77.5 \%$ and $70.4 \%$, respectively).

The other two anatomy sub-disciplines, embryology and histology, were rated considerably lower than its discipline counterparts. Histology was among the lowest rated in importance with about two thirds of the respondents seeing it as only slightly or moderately important and $6.5 \%$ as not important at all for practice. Embryology fared considerably better with $73.4 \%$ of the respondents perceiving it as quite or very important.

The lowest rated sub-disciplines were biochemistry and microbiology with about two thirds of respondents rating them as only slightly or moderately important.

There was a statistically significant association between gender and rating the relevance of pathology and pharmacology respectively $(p$-value $=0.015$ and 0.001$)$. Age 
Table I. Attitudes towards the clinical relevance of 13 disciplines (expressed as a percentage of respondents).

\begin{tabular}{|c|c|c|c|c|c|c|}
\hline Discipline & $\begin{array}{c}\text { No } \\
\text { answer }\end{array}$ & $\begin{array}{c}\text { Not } \\
\text { important }\end{array}$ & $\begin{array}{l}\text { Slightly } \\
\text { important }\end{array}$ & $\begin{array}{l}\text { Moderately } \\
\text { important }\end{array}$ & $\begin{array}{c}\text { Quite } \\
\text { important }\end{array}$ & $\begin{array}{c}\text { Very } \\
\text { important }\end{array}$ \\
\hline Sub-disciplines of Anatomy & 0 & 0.6 & 9.5 & 16.6 & 36.1 & 37.3 \\
\hline $\begin{array}{l}\text { Embryology } \\
\text { Histology }\end{array}$ & 0.6 & 6.5 & 26 & 379 & 172 & 118 \\
\hline Gross anatomy & 0 & 0 & 0 & 0 & 1.8 & 98.2 \\
\hline Neuroan atomy & 0 & 0 & 0 & 1.2 & 14.2 & 84.6 \\
\hline Disciplines other than & 3.6 & 3 & 28.4 & 29.6 & 25.4 & 10.1 \\
\hline Anatomy Biochemistry & & & & & & \\
\hline Biomechanics & 0.6 & 0 & 0 & 0.6 & 13 & 85.8 \\
\hline Microbiology & 0.6 & 6.5 & 26.6 & 33.1 & 24.3 & 8.9 \\
\hline Neurology & 1.2 & 0 & 0 & 1.2 & 20.1 & 77.5 \\
\hline Pathology & 0.6 & 0 & 0 & 7.7 & 23.1 & 68.6 \\
\hline Pharmacology & 1.2 & 0.6 & 6.5 & 25.4 & 42 & 24.3 \\
\hline Physical Examination & 0 & 0 & 0 & 0 & 5.3 & 94.7 \\
\hline Physiology & 0 & 0 & 0 & 5.3 & 24.3 & 70.4 \\
\hline Radiology & 0 & 0 & 1.2 & 9.5 & 31.4 & 58 \\
\hline
\end{tabular}

was also associated with the ratings of some of the other disciplines studied, including biochemistry ( $\mathrm{p}$-value $=0.003$ ), biomechanics ( $\mathrm{p}$-value $<0.0005)$, microbiology $(\mathrm{p}$-value $=$ 0.036 ) and pathology ( $\mathrm{p}$-value $<0.0005$ ). A rating difference was not detected between years of graduation or place of graduation, possibly due to the small sample sizes in each year of graduation and place of graduation.

\section{DISCUSSION}

Participants in this study perceived the anatomy and neuroanatomy sub-disciplines of anatomy as very important in osteopathic practice. Embryology was seen as somewhat less important. Of the anatomy sub-disciplines, histology was perceived as least relevant in training for the clinical practice.

Considering the tactile nature of manual therapy in osteopathic treatments and its focus on the musculoskeletal system, the order of importance of the disciplines is expected. This however, does not account for the considerable difference in the perceptions of importance in practice. A possible explanation for this could be that there exists a natural scaffolding of anatomical knowledge gained from the gross anatomy, neuroanatomy and biomechanics disciplines, to its clinical application, as these subjects are integrated and foundational for physical examination. Consequently, it would correlate that gross anatomy and neuroanatomy are easily perceived by practitioners as clinically relevant subjects.

The present study's findings concur considerably with results of similar studies conducted among medical and allied health professionals and students in different countries. In osteopathy, Thomson et al. (2014) study of practitioners' perceptions of clinical practice revealed that the practitioners see "propositional knowledge such as anatomy and biomechanics" as "central to their knowledge base and technical expertise". This finding was corroborated in the current study as anatomy and biomechanics were see as clinically highly valuable subjects. However the current study also highlighted that not all sub-disciplines of anatomy were equally valued and that while gross anatomy and neuroanatomy are seen an as very important by large majority of practitioners, this was not the case with embryology and even more with histology. This information is important given the significant developments that emerge from research in disciplines such as embryology, cell biology, and even immunology that have a direct bearing on the current understanding of musculoskeletal pathologies and its management.

In medicine, Pabst \& Rothkötter $(1996,1997)$ surveyed German graduates at the time of their graduation and several years later. Final year medical students $(n=323)$ were asked to grade the relevance of all the courses (subjects) within their medical studies. A total of $91 \%$ of respondents rated gross anatomy as fundamental with respect to their relevance in becoming a doctor (Pabst \& Rothkötter, 1996). This compared very favourably with ratings of other subjects; i.e. physiology was rated as "fundamental" by $77 \%$, "necessary" by $19 \%$, "of little relevance" by $3 \%$, and "superfluous" by $1 \%$ (Pabst \& Rothkötter, 1996). This is very similar to the rating of gross anatomy and physiology in this study. Additionally, Pabst \& Rothkötter (1997) asked medical doctors at the end of their postgraduate specialisation training period (average of seven years after graduation) to rate how relevant lectures and courses (undergraduate) were for training to become a doctor. Of the 109 respondents, gross anatomy was regarded as "fundamental" by $86 \%$ and "necessary" by $13 \%$. Only the course of internal medicine rated as high, with $88 \%$ rating it as "fundamental" (Pabst \& Rothkötter, 1997). 
In the USA, Lazarus et al. surveyed third and fourth year medical students $(n=67)$, clinical physicians $(n=120)$, and academic anatomists $(n=44)$. The mean group ranking of the perceived importance of anatomy to the clinical setting within all three groups was higher than 8.6 on an eleven point Likert scale (where $0=$ not essential and $10=$ critical) with the students group rating mean of 8.5 , the clinical physicians' mean of 8.9 and the academic anatomists' mean was 9.5 (Lazarus et al.). Similarly, Moxham \& Plaisant surveyed 339 first year medical students and 344 final year medical students studying in Cardiff, Wales and in Paris, France. All students demonstrated an overwhelmingly positive attitude towards the relevance of gross anatomy to clinical medicine, so much so that not a single student responded negatively (Moxham \& Plaisant). These findings were further corroborated in a study surveying medical students from the medicals schools in Cardiff (UK), Paris, Descartes/Sorbonne (France), St George's University (Grenada and Ankara (Turkey), where it was confirmed that "regardless of geopolitical and cultural backgrounds, students at all stages (early and late) of their medical studies share the view that gross anatomy is very important in clinic" (Moxham \& Plaisant).

Further probing into attitudes towards various topics in anatomy demonstrated that clinicians, depending on their specialty and clinical affiliation, have different perceptions of the importance of these topics (Orsbon et al., 2014). Similarly, a survey completed in Ireland detected differences between medical students, clinicians and anatomists in their attitudes towards anatomy delivery and its place in medical curriculum (Sbayeh et al., 2016).

This very positive view of anatomy is shared by other health professions. Chiropractic students at an Australian university reported a very strong positive attitude towards anatomy (Strkalj et al.). All 157 respondents agreed with at least one of the positive statements contained in the survey (Strkalj et al.). In contrast, and similar to the results of the current study, only $60.7 \%$ of the fifth year students and $58.2 \%$ of first year students showed a positive attitude to the clinical relevance of chemistry (Strkalj et al.). In Turkey, a series of interviews were conducted with 50 physiotherapists focusing on their anatomy education (Duman et al.). While the modes of their delivery and perception of their adequacy varied, "the effect of the anatomyeducation on the clinical course was largely considered to be very important" (Duman et al.).

Current research on the clinical relevance of anatomy in medicine and other health professions, including the present study, strongly suggests that anatomy is perceived, by students and clinicians alike, as very important for clinical practice and therefore a cornerstone of professional training. However, when anatomy is "unpacked" into its sub-discipline, this survey suggests that the perceived importance may vary between embryology, histology, gross anatomy and neuroanatomy. It can be hypothesised that the difference in emphasis on sub-disciplines of anatomy varies between various health professions. In osteopathy, because of its clinical focus, gross anatomy and neuroanatomy are perceived as subject of special importance. These findings and idiosyncrasies should be taken into account when devising anatomy curricula for osteopathic programs (Moxham et al., 2014) as well as program accreditation requirements. They should be of particular importance when allocating time and resources for anatomy delivery, especially in light of the recent trends in anatomy education, which include significant reduction in time dedicated to the subject (Paulsen et al.).

It would appear that in spite of numerous changes in modern health professions curricula, anatomy remains one of their most important constituents. This study suggests that osteopathic practitioners see gross anatomy and neuroanatomy as subjects of high importance in their professional training while embryology and particularly histology are seen as somewhat less important. Due attention should be made to these findings when planning osteopathic curricula and program accreditation requirements.

BLAICH, R.; PATHER, N.; LUO, K. \& STRKALJ, K. Percepciones de los practicantes de osteopatía australianos de la relevancia clínica de la anatomía. Int. J. Morphol., 37(1):319-323, 2019.

RESUMEN: La anatomía es una disciplina fundamental en la formación de profesionales de la salud. Sin embargo, hay poca literatura sobre la importancia relativa de la anatomía, especialmente en relación con las otras ciencias biomédicas y los dominios clínicos, en la preparación de profesionales de la osteopatía para la práctica clínica. Este estudio tuvo como objetivo examinar las percepciones de los médicos osteopáticos australianos sobre la importancia relativa de la anatomía en su formación profesional y práctica clínica, especialmente en relación con otras ciencias biomédicas y dominios clínicos dentro de los currículos osteopáticos. El estudio también examinó la importancia percibida de las subdisciplinas de la anatomía para la práctica profesional. Se realizó una encuesta basada en un cuestionario entre los profesionales osteopáticos australianos en varias reuniones nacionales en 2014 y 2015. Utilizando una escala Likert de cinco puntos, se pidió a todos los encuestados que calificaran la relevancia de las siguientes trece disciplinas y subdisciplinas para la práctica clínica: Biomecánica, bioquímica, embriología, histología, anatomía macroscópica, microbiología, neuroanatomía, neurología, patología, farmacología, exploración física, fisiología y radiología. De los 175 practicantes encuestados, 169 respondieron (es decir, una tasa de respuesta del 96,6\%). Dos de las subdisciplinas de la ana- 
tomía estaban entre las mejor calificadas, con un 98,2\% que percibían la anatomía general como "muy importante", mientras que la neuroanatomía se calificaba como "muy importante" en un 84,6\% y "muy importante" en un $14,2 \%$. También se dio una calificación alta similar a la biomecánica y el examen físico, mientras que las otras dos subdisciplinas, embriología e histología recibieron calificaciones más bajas. No se identificaron diferencias significativas en las calificaciones con respecto al año de los participantes y el lugar de graduación. Sin embargo, hubo una asociación entre el sexo y la calificación en Patología y Farmacología respectivamente, así como los efectos de la edad en las calificaciones de varias subdisciplinas. Estos hallazgos son generalmente consistentes con los resultados de encuestas similares realizadas sobre la importancia clínica de la anatomía, en otros profesionales de la salud médicos y afines en diferentes países. En general, los profesionales de la osteopatía tienen una percepción positiva de la relevancia de la anatomía, en particular la neuroanatomía general y la neuroanatomía, para la práctica clínica, lo que se debe tener en cuenta al desarrollar los currículos osteopáticos.

PALABRAS CLAVE: Anatomía; Educación; Osteopatía; Desarrollo curricular.

\section{REFERENCES}

Australasian Osteopathic Accreditation Council (AOAC). Accreditation Standards for Osteopathic Courses in Australia. Canberra, Australasian Osteopathic Accreditation Council, 2016. Available from: https:// osteopathiccouncil.org.au/wp-content/uploads/2016/11/ AOAC_AccreditationStandardsJuly 16.pdf

Duman, F.; Huzmeli, I.; Yucekaya, B.; Hallaceli, H. \& Gunes, M. Importance of anatomy education in physical therapy and rehabilitation in Turkey: A qualitative study. New Trends Issues Proc. Humanit. Soc. Sci., 4(4):64$71,2017$.

Estai, M. \& Bunt, S. Best teaching practices in anatomy education: A critical review. Ann. Anat., 208:151-7, 2016.

Giuriato, R.; Pather, N.; Ashwell, K. \& Strkalj, G. The role of anatomy education in facilitating multidisciplinary collaboration in the treatment of musculoskeletal conditions - an example from Australia. Int. J. Morphol., 34(4):1424-8, 2016.

Lazarus, M. D.; Chinchilli, V. M.; Leong, S. L. \& Kaufman, G. L. Jr. Perceptions of anatomy: critical components in the clinical setting. Anat. Sci. Educ., 5(4):187-99, 2012.

Moxham, B. J. \& Plaisant, O. Perception of medical students towards the clinical relevance of anatomy. Clin. Anat., 20(5):560-4,2007.

Moxham, B. J.; Plaisant O.; Smith, C. F.; Pawlina W. \& McHanwell, S. An approach toward the development of core syllabuses for the anatomical sciences. Anat. Sci. Educ., 7(4):302-11, 2014.

Orsbon, C. P.; Kaiser, R. S. \& Ross, C. F. Physician opinions about an anatomy core curriculum: a case for medical imaging and vertical integration. Anat. Sci. Educ., 7(4):251-61, 2014.

Osteopathy Australia. About Osteopathy. Chatswood, Osteopathy Australia, 2018. Available from: https://www.osteopathy.org.au/pages/aboutosteopathy.html

Pabst, R. \& Rothkötter, H. J. Retrospective evaluation of undergraduate medical education by doctors at the end of their residency time in hospitals: consequences for the anatomical curriculum. Anat. Rec., 249(4):431-4, 1997.

Pabst, R.; \& Rothkötter, H. J. Retrospective evaluation of a medical curriculum by final-year students. Med. Teach., 18(4):288-93, 1996.
Paulsen, D. F.; Klement, B. J. \& Wineski, L. E. Role of Anatomists in Building an Integrated Medical Curriculum. In: Chan, L. K. \& Pawlina, W. (Eds.). Teaching Anatomy: A Practical Guide. New York, Springer, 2015. pp.331-7.

Persaud, T. V. N.; Loukas, M. \& Tubbs, R. S. A History of Human Anatomy. $2^{\text {nd }}$ ed. Springfield, Charles C. C. Thomas Publications, 2014.

Plaisant, O.; Stephens, S.; Apaydin, N.; Courtois, R.; Lignier, B.; Loukas, M. \& Moxham, B. Medical students' attitudes towards science and gross anatomy, and the relationship to personality. J. Anat., 224(3):261-9, 2014.

Sbayeh, A.; Qaedi Choo, M. A.; Quane, K. A.; Finucane, P.; McGrath, D.: O'Flynn, S.; O'Mahony, S. M. \& O'Tuathaigh, C. M. Relevance of anatomy to medical education and clinical practice: perspectives of medical students, clinicians, and educators. Perspect. Med. Educ., 5(6):338-46, 2016.

Shank, M. F. Importance of teaching anatomy. JAMA, 252(6):765-6, 1984

Still, A. T. Philosophy of Osteopathy. Indianapolis, American Academy of Osteopathy, 1899.

Strkalj, G.; Luo, K. \& Rigney, C. T. Attitudes of Australian chiropractic students towards anatomy and chemistry. Anthropologist, 18(1):1918, 2014.

Thomson, O. P.; Petty, N. J. \& Moore, A. P. A qualitative grounded theory study of the conceptions of clinical practice in osteopathy - a continuum from technical rationality to professional artistry. Man. Ther., 19(1):3743, 2014.

Turney, B. W. Anatomy in a modern medical curriculum. Ann. R. Coll. Surg. Engl., 89(2):104-7, 2007.

Corresponding author:

Raymond Blaich

School of Health and Human Sciences

Southern Cross University

Military Road East

Lismore, NSW 2480

AUSTRALIA

Email: raymond.blaich@scu.edu.au

Received: $26-07-2018$

Accepted: $12-12-2018$ 